MareK CetwińsKi

(Częstochowa)

\title{
Gustaw Adolf Harald Stenzel i jego wizja ustroju Polski piastowskiej
}

\section{Gustaw Adolf Harald Stenzel und seine Vorstellung der Staatsform im Polen der Piasten}

1. Dorobek Gustawa Adolfa Haralda Stenzla. 2. Jego metoda. 3. Śląsk za czasów polskich według Stenzla. 4. Rola miast. 5. Wizja Bobrzyńskiego. 6. Stenzel w polskiej historiografii.

1. Die Errungenschaften von Gustaw Adolf Stenzel. 2. Seine Methode. 3. Schlesien unter der polnischen Macht aus Stenzels Sicht. 4. Rolle der Städte. 5. Vorstellung von Bobrzyński. 6. Stenzel in der polnischen Geschichtsforschung.

Michał Bobrzyński pisał we Wstẹpie do swoich Dziejów Polski w zarysie, iż nie znalazly $w$ literaturze polskiej wspólzawodnictwa prace niemieckie Ludwiga Giesebrechta, Johannesa Voigta i Gustawa Adolfa Stenzla. O wydawnictwie tegoż Stenzla, Urkundensammlung zur Geschichte des Ursprungs der Städte und die Einfürung und Verbreitung Deutscher Kolonisten und Rechte in Schlesien und der Ober-Lausitz' ${ }^{1}$, które ukazało się w Hamburgu w 1832 r., notuje, że zawiera $w$ przedmowie najdawniejszq historie prawa polskiego ${ }^{2}$. Idzie o to samo dziclo, które zdaniem Georga von Belowa stalo się wzorem dla prac analizujących dzieje niemicckiej kolonizacji niemieckiego Wschodu i Pólnocy ${ }^{3}$. Josef Joachim Menzel jeszcze w 1977 r. pisał o przelomowym znaczeniu tej pracy Stenzla ${ }^{4}$. Warto zastanowić się zatem, choćby z uwagi na popularność

${ }^{1}$ Cyt. dalej jako: Stenzel, Tzschoppe.

${ }^{2}$ M. B obrzyński, Dzieje Polski w zarysie, Warszawa 1986, s. 65.

${ }^{3}$ G. v on B elow, Die deutsche Geschichtschreibung von den Befreiungskriegen bis zu unsern Tagen. Geschichtschreibung und Geschichtsauffasung. Mit einer Beigabe: die deutsche Wirtschaftsgeschichtliche Literatur und der Ursprung des Marxismus, München-Berlin 1924, s. 171, $z$ powołaniem się na $F$. Rachfahla.

4 J. J. Menze1, Die schlesischen Lokationsurkunden des 13. Jahrhunderts. Studien zum Urkundenwesen, zur Siedlung-, Rechts- und Wirtschaftsgeschichte einer ostdeutschen Landschaft im Mittelalter, Würzburg 1977, s. 284. 
dzieła Bobrzyńskiego, czy rekomendowane w niej opracowanie niemieckiego historyka wywarło wpływ również na badaczy polskich. W pierwszym zaś rzędzie na samego Michała Bobrzyńskiego.

Gustaw Adolf Harald Stenzel - zdaniem Franza Xavera von Wegelego, autora monumentalnej historii historiografii niemieckiej - należał do najdzielniejszych i najwydatniejszych pracowników na polu niemieckich dziejów, zwlaszcza średniowiecznych. Jest też uważany - obok Leopolda Rankego, z którym utrzymywał zresztą kontakt listowy - za współtwórcę naukowego dziejopisarstwa niemieckiego; lączy się go czasem ze stworzoną przez Friedricha Karla von Savigny'ego i Karla Friedricha Eichhorna ,historyczną szkołą prawa". Szczególne zasługi położył Stenzel w badaniach historii Śląska, nie tylko jako autor historii tej krainy (1853), ale i także jako wydawca źródel. I tak opublikowal pięć tomów serii Scriptores rerum Silesiacarum (1835-1851), Das Landbuch des Fürstenthums Breslau (1843), Urkunden zur Geschichte des Bisthums Breslau im Mittelalter (1845), Liber fundationis claustri Sanctae Mariae Virginis in Heinrichow oder Gründungsbuch des Kloster Heinrichau (pośmiertnie w 1854) oraz wiele innych przyczynków źródłowych i rozpraw. Wśród takich to dzieł znajduje się też „książka w książce” - wspomniana przez Bobrzyńskiego „najdawniejsza historia prawa polskiego", zajmująca niemal trzysta stron druku wstępu do zbioru dokumentów obrazujących powstanie śląskich miast na prawie niemieckim. Wprawdzie na karcie tytułowej widnieje obok Stenzla także Gustaw Adolf Tzschoppe - wysokiej rangi urzędnik dworu pruskiego, to - jak stwierdził Wilhelm Dersch - opracowanie jest wylqcznie dzielem Stenzla?.

Stenzel zaczyna od stwierdzenia nie dla wszystkich wówczas oczywistego faktu, że Lüneburg, Altmark, Turyngia, Frankonia, Austria, Karyntia, Steiermarck, Królestwo Saksonii, Holsztyn, Meklemburgia, Rugia, Pomorze, Łużyce i Śląsk zamieszkałe obecnie przez Niemców, niegdyś były słowiańskie.

${ }^{5}$ F. X. von Wegele, Geschichte der deutschen Historiographie seit dem Auftreten des Humanismus, München-Leipzig 1885, s. 1023. Podstawowe dane zob. biogram Stenzla pióra E. Reimanna (Deutsche Allgemeine Biographie, t. 36, Drunken u. Humboldt, Berlin 1970 (Facsimile de 1'ed. 1889), s. 53-57). Dotrzega się też wpływ myśli Johanna von Müllera na twórczość Stenzla; wyraźne to w podejmowaniu tematyki społecznej.

${ }^{6} \mathrm{G}$. von $\mathrm{Below}$, Die deutsche..., s. 171. Związki te są widoczne zwłaszcza w przedmowie do wydawnictwa (Stenzel, Tzschoppe) zarówno przy bezpośrednim powołaniu się na pracę K. F. Eich hor na, Deutsche Staats- und Recht-Geschichte (s. 237, przyp. 10), jak i tezach wywodu końcowego (s. 263-265), gdzie porównanie oświeceniowego państwa do wspaniale rozplanowanego, lecz absolutnie nieprzytulnego pałacu, zaś ,starego państwa" i „starej gminy" do tworu Natury. Państwo oświeceniowe, obce tradycjom ludu, jawi się - zdaniem Stenzla - niemal jako wampir wysysający krew z żył społeczeństwa.

${ }^{7}$ W. Dersch, Ein Jahrhundertgedächtnis, Schlesisches Geschichtsblätter 1932, nr 2, s. 31. Tzschoppe zdobył fundusze na druk publikacji. 
$\mathrm{O}$ autochtonach przypomina zaledwie kilka zachowanych stów, wiele nazw miejscowych, nazwiska kilku szlacheckich rodzin $i$ male samotne wysepki jezykowe; wszystko to przypomina strzaskane fundamenty dawnej budowli, na $k$ tórej dziś stoi nowy dom ${ }^{8}$. Dzieje rozprzestrzeniania się Niemców i niemieckiej kultury, ustalenie przyczyn tego zjawiska to - sądzi Stenzel - istotne zadania historyków9 9 Problem wpływów niemieckich na polską kulturę nurtował go zresztą już podczas studiów, kiedy napisal, nagrodzoną przez fundacje Jabłonowskich, pracę Über den Einfluss der Deutschen auf die polnische Kultur. Już wówczas ten weteran prowadzonej przeciwko Napoleonowi niemieckiej wojny wyzwoleńczej i przyszły liberalny polityk podejrzewal, że czynnikiem decydującym o atrakcyjności niemieckiej kultury było niemieckie prawo gwarantujące podstawowe wolności jednostkom. Poszukiwania historyczne Stenzla wynikały z jego politycznych przekonań. Historia to - jego zdaniem - postępy idei wolności. Prawo gwarantujące wolność musi jednak odpowiadać historycznie ukształtowanym cechom danej społeczności. Pisal o tym we wstępie do interesującego nas zbioru dokumentów:

Alles besthende Recht, wie jedes festbegründete, allgemeinere Verhältniss, hat seine Wurzel in der Vergangenheit. Ohne Kenntniss derselben, kann das Recht, seinem Wesen und den inneren Gründen seines Entstehens nach, nie klar begreiffen werden. Eben so wichtig wie philosophischer Geist, ist dem Rechtsgelehrten die Geschichtskenntniss ${ }^{10}$.

W słowach tych łatwo dostrzec echo wywodów Savigny'ego z wydanej w 1814 r. słynnej pracy $O$ powolaniu naszych czasów do ustawodawstwa i nauki prawa:

...wszelkie prawo powstaje jako owoc działania sił wewnętrznych, które pracują w milczeniu, a nie $\mathrm{z}$ woli prawodawcy ${ }^{11}$.

Podobnie jak twórca „historycznej szkoły prawa” uważał Stenzel, że materia prawa jest dana przez caloksztalt przeszlości narodowej. Materia owa może być taka czy inna, to rzecz obojetna, byleby tylko wynikala z najglebszej istoty narodu ${ }^{12}$. Z kolei ,filozoficzny duch" to aluzja do Heglowskiego „ducha

\footnotetext{
${ }^{8}$ Stenzel, Tzschoppe, s. V.

'Ibidem, s. V-VI.

${ }^{10}$ Ibidem, s. VI.

11 Por. G. C o c ch i a r a, Dzieje folklorystyki w Europie, thum. W. Jekiel, Warszawa 1971, s. 237.

12 Loc. cit:: pogląd to $w$ Niemczech wówczas powszechny m.in. dzięki popularności dzieła E. Burke, Reflections on the Revolution in France w thumaczeniu wroclawianina F. von Gentz (Braunschweig 1793); por. polskie thm. pt. Rozważania o rewolucji we Francji, thum. D. Lachowska, Kraków 1994. Niemiecki romantyzm, jak widać, karmil się nie tylko „Pieśniami Osjana”, ale też „szkockim oświeceniem” porównującym państwo do „żywego organizmu”.
} 
dziejów". Liberal Stenzel podzielał zdanie filozofa, jakoby Niemcy byly $z$ tradycji narodem wolnym ${ }^{13}$. Historia Niemców to $\mathrm{w}$ konsekwencji dzieje realizacji wolności. Za tym powszechnym wtedy poglądem uważa wrocławski historyk, że zasadnicza rola $\mathrm{w}$ walce $\mathrm{z}$ samowolq $i$ gwaltami feudalizmu przypadła miastom jako pierwszej potędze prawnej ${ }^{14}$. Pojawienie się miast wyznacza więc narodziny społeczeństwa rządzącego się siłą prawa, a nie prawem sily. Przed powstaniem miast mamy do czynienia $z$ feudalizmem. A zasadq ustroju feudalnego - głosi Hegel - jest zewnętrzna wladza jednostek, książat, możnowladców bez zasady prawa w sobie samych. Obowiązki i wladza są wówczas wynikiem uźycia siły i jedynie nieustanna przemoc może zapewnić ich wykonywanie $e^{15}$.

\section{2}

$\mathrm{Z}$ takim to zestawem idei, niezwykle wówczas w Niemczech popularnych, przystapił Stenzel do opublikowanej w 1832 r. "historii najdawniejszego prawa polskiego". Pamiętać wszak należy, że historia ta to w zamyśle autora zaledwie wstęp do właściwego tematu - historii niemieckiego mieszczaństwa na Śląsku. A Niemcy są - uważano wtedy $-z$ tradycji wolnym narodem. Opublikowane w zbiorze 209 dokumentów stanowiło ilustrację powyższego przekonania. Zbiór to przewyższający liczebnie - zapewnia Stenzel - dokonania poprzedników ${ }^{16}$. Nie jest to jednak zbiór kompletny. Zebrano w nim najbardziej pouczające dokumenty lokacji wsi, „wszystkie" dokumenty lokacji na prawie niemieckim miast śląskich oraz ,ważniejsze" poświadczenia prawa magdeburskiego dla miast Śląska i Górnych Łużyc ${ }^{17}$. Inspiracją do poszukiwań stała się - wyjaśnia Stenzel - prośba wroclawskiego magistratu z 1824 r. o odnalezienie najstarszego dokumentu prawa magdeburskiego ${ }^{18}$. W miarę postępu poszukiwań archiwalnych konkretyzowal się ich cel: przedstawienie stosunków panujących na Śląsku w czasie pojawienia się tu niemieckich kolonistów oraz zmian, jakie nastąpily wraz $\mathrm{z}$ wprowadzeniem prawa niemieckiego.

Stenzel starannie wymienia i ocenia wiarygodność zebranych źródeł. Największą wartość przedstawiają, jego zdaniem, oryginały dokumentów.

${ }^{13}$ G. W. F. H ege1, Wyklady z filozofii dziejów, t. II, thum. J. Grabowski, A. Landman, Warszawa 1958 , s. 239. Z przyczyn oczywistych Stenzel nie mógł z tym właśnie dziełem Hegla zapoznać się, sama teza była jednak obiegową wówczas opinią. Intelektualne to ówczesnej nauki niemieckiej zob. T. K r oński, Hegel, Warszawa 1966; t e nże, Wstęp [do:], G. W. F. Hege 1, Wyklady z filozofii dziejów, Warszawa 1958, s. VI-LXXVII.

14 Ibidem, s. 256.

15 Ibidem, s. 277.

${ }^{16}$ Stenzel, Tzschoppe, S. VI.

17 Ibidem, s. VII.

${ }^{18}$ Loc. cit. 
Kolejno idą zapisy współczesne $\mathrm{z}$ ksiąg ziemskich i wreszcie źródła zawarte w młodszych, głównie $\mathrm{z}$ XV i XVI w., księgach miejskich i kopiarzach $^{19}$. Szczególna rola przypadła sporządzonemu w latach 1550-1568 repertorium Eliasza - opata klasztoru kanoników regularnych na wroclawskim Piasku ${ }^{20}$. To $\mathrm{z}$ niego czerpie Stenzel wyjaśnienia dotyczące rodzaju powinności prawa polskiego: „poradlne”, „podvorove”, „powoz”, „prevod”, „preseca” i „stroza" zdaje sobie Stenzel sprawę, być trafne. I tak, przytaczając thumaczenie opata, iż ,poradlne”, jeden z najstarszych - jak uważa - ciężarów prawa polskiego - to czynsz $\mathrm{w}$ wysokości 2 groszy polskich $\mathrm{z}$ lana, słusznie dopatruje się tu wiedzy o postanowieniach z czasów Ludwika Węgierskiego $^{22}$. Wrocławski historyk nie określa czasu powstania ciężarów prawa polskiego. Stwierdza tylko, że te $\mathrm{z}$ nich, które znane są pod tą samą nazwą $w$ innych częściach Polski, pochodzą sprzed 1163 r., kiedy to - jak sądzi - wraz z powrotem synów Władysława Wygnańca Śląsk stal się niezależnym od Polski ${ }^{23}$. Do ostrożności skłania go fakt, iż w $1232 \mathrm{r}$. papież Grzegorz IX pisze o wprowadzaniu przez polskich książąt nowych, wcześniej nieznanych obowiązków poddanych ${ }^{24}$. Nie o chronologię poszczególnych ciężarów prawa polskiego bowiem chodzi Stenzlowi, lecz o przedstawienie istoty stosunków panujących w Polsce przed naplywem Niemców.

Książęta polscy mieli - zdaniem wrocławskiego uczonego - prawa podobne tym, jakie przysługiwały cesarzom ${ }^{25}$. Do nich należało najwyższe sądownictwo, regale górnicze, mennicze, solne, celne, lowieckie. A co dla interesującego Stenzla problemu, najistotniejsze było to, że książęta mieli wyłączne prawo zakładania targów i miast ${ }^{26}$. Rywalami książąt śląskich byli wroclawscy biskupi. $\mathrm{O}$ pierwszych latach historii tutejszego biskupstwa zachowały się tylko „bajeczne” przekazy z XIV i XV w. ${ }^{27}$ Wiarygodne dokumenty pojawiaja

19 Ibidem, s. IX-XV.

${ }^{20}$ Ibidem, s. X.

${ }^{21}$ Ibidem, s. 10, 11, 14, 17, 23, 28.

22 Ibidem, s. 10.

${ }^{23}$ Ibidem, s. 2. Przekonanie o podobieństwie ustroju Śląska i pozostałych ziem Polski wspiera Stenzel tym, że skoro dynastia i szlachta śląska była polska, to i stosunki społeczne w XII-XIII $w$. panujące tu wówczas były jak $w$ Polsce.

${ }^{24}$ Ibidem, s. 21.

${ }^{25}$ Ibidem, s. 5.

${ }^{26}$ Ibidem, s. 5-9.

${ }^{27}$ Ibidem, s. 32. 
się dopiero $\mathrm{z}$ bullą Hadriana IV $\mathrm{z}$ roku $1155^{28}$. Historia wrocławskiego biskupstwa to dzieje walk i sporów $\mathrm{z}$ książętami i rycerstwem, głównie o dziesięciny ${ }^{29}$. W walce tej charakterystyczna jest - zdaniem Stenzla - ustępliwość książąt i upór rycerstwa sprzeciwiającego się umocnieniu potęgi Kościoła. Dopiero współdziałanie władcy świeckiego i duchowieństwa zmusiło szlachtę do ustępstw ${ }^{30}$. Ustępliwość książąt wobec duchowieństwa wynikała - domyśla się uczony - z chęci uniezależnienia się od szlachty, bez zgody której przynajmniej od drugiej połowy XII w., władca nie mógł przedsięwziąć niczego poważniejszego ${ }^{31}$. Wzrastająca, wraz $\mathrm{z}$ pogłębiającym się rozbiciem dzielnicowym, rola możnych nieprzypadkiem może - podejrzewa Stenzel - odpowiada czasowo pojawianiu się wiarygodnych przekazów $\mathrm{z}$ dziejów wrocławskiego biskupstwa. Wraz $\mathrm{z}$ rozbiciem dzielnicowym rozpoczęła się walka książąt $\mathrm{z}$ możnymi, możnych $\mathrm{z}$ Kościołem i tegoż Kościoła $\mathrm{z}$ książętami. Broniąc się przed zdominowaniem przez możnowładztwo, książęta szli na ustępstwa wobec duchowieństwa.

Właśnie w tej sytuacji, walki wszystkich z wszystkimi, wrócili z Niemiec na Śląsk synowie Władysława Wygnańca. Najstarszy z nich Bolesław nadał w 1175 r. przywilej zezwalający klasztorowi w Lubiążu sprowadzać niemieckich kolonistów. Dokument ten wyznacza w przekonaniu Stenzla początek niemieckiej kolonizacji $w$ tej dzielnicy ${ }^{32}$. Śladem Lubiąża podążyły inne klasztory ${ }^{33}$. Koloniści przybywali głównie $z$ tej części Niemiec, gdzie znajomość języka słowiańskiego była powszechna, łatwo było im więc zadomowić się na Śląsku ${ }^{34}$. Czynnikiem zachęcającym przybyszów do osiedlenia się na Śląsku było zwolnienie ich od ciężarów prawa polskiego, głównie od tego, co stanowiło istotę tego prawa - osobistego poddaństwa ${ }^{35}$. Stenzel zna wprawdzie wzmianki $o$ istnieniu $w$ czasach niemieckiej kolonizacji wolnych polskich chłopów, ale nie przywiązuje do nich większej wagi ${ }^{36}$. Stwierdza apodyktycznie, że ze wzmianek tych wynika, co najwyżej, skoro ich także przenosi się na prawo niemieckie, iż może wolni byli, ale z całą pewnością wolnymi się stali dzięki przyjęciu nowego prawa ${ }^{37}$. Chłopi polscy, nawet ci określani jako ,servi", to nie tyle „niewolnicy” w klasycznym tego stowa znaczeniu, lecz „poddani” (Leibeigene) zu einem bestimmten Grundstücke oder Gute

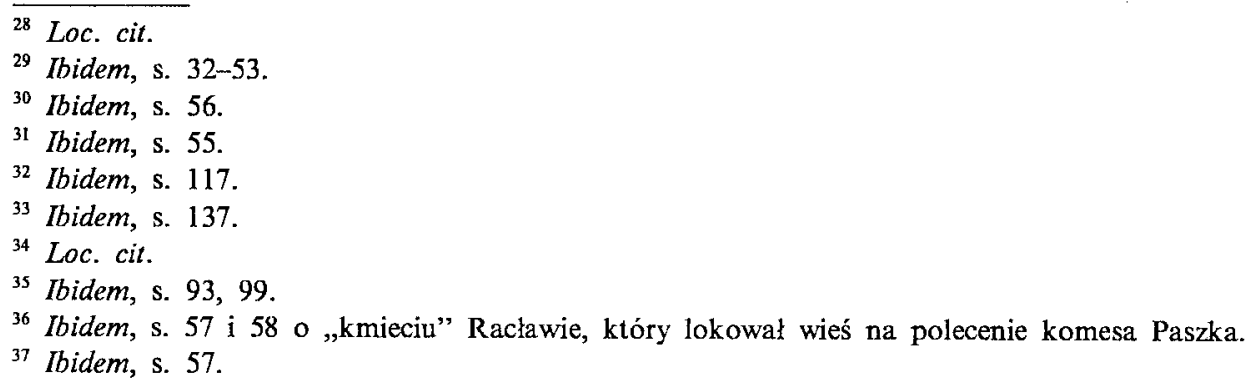


gehörige Bauern oder Dienstleute ${ }^{38}$. Sprzedawano więc owych poddanych, ściślej: ich powinności razem $\mathrm{z}$ ziemią ${ }^{39}$. Arbitralnie zmieniano też rodzaj owych powinności. I tak łowcy, których Henryk Brodaty podarowal klasztorowi w Trzebnicy, mieli odtąd zamiast myślistwem trudnić się innym rzemiosłem ${ }^{40}$. Położenie polskich chłopów ist bis jetzt, ungeachtet aller Bemühungen nur wenig Licht verbreitet worden. Daß die Polnischen Bauern, wahrscheinlich die, von den Erobern oder dem Adel, unterworfenen Eingeborenen, bereits im zehnten und im Anfange des elften Jahrhunderts vom Adel hast gedrückt wurden, erfahren wir uns der Nachricht von dem Schutze, welchen ihnen Herzog Boleslaus I. von Polen angedeichen lie $\beta^{41}$. Od tego czasu ich położenie stale się pogarszało.

Wydaje się, że obraz ciemiężonego chłopa pańszczyźnianego to wynik odczytywania przez Stenzla średniowiecznych źródel śląskich przez filtr wiedzy o współczesnych mu stosunkach spolecznych na ziemiach polskich. Inne uwagi wroclawskiego historyka także wywodzą się $\mathrm{z}$ panujących $\mathrm{w}$ jego epoce stereotypów. I tak ze zrozumieniem odnotowuje: $D a \beta$ überhaupt die Polen als weniger geeignet zum fleißigen Anbau des Landes angesehen wurden, sprach Bischof Johann von Breslau i. J. 1495 gerade zu aus ${ }^{42}$. Biskup groził swym poddanym, którzy $w$ ciągu najbliższych pięciu lat nie opanują niemieckiego, usunięciem z uprawianego gruntu. Pojęcie polnische Wirtschaft, odnotowane przez Johanna Georga Forstera w 1785 r., zdaje się być istotnym także dla myśli historycznej Stenzla ${ }^{43}$. Utwierdza w tym podejrzeniu pogląd wrocławskiego historyka, iż do zwycięstwa niemieckiej kultury na Śląsku, pomimo rozproszenia niemieckich kolonistów wśród słowiańskich tubylców, przyczyniły się dwa czynniki: ...natürliche Macht der höhern Bildung oraz persönliche Freiheit und die vertheilhaftere Verhältniße überhaupt, welche das Deutsche Recht gab ${ }^{44}$.

${ }^{38}$ Loc. cit.

${ }^{39}$ Loc. cit.

${ }^{40}$ Ibidem, s. 61.

${ }^{41}$ Ibidem, s. 56. Z przekonaniem o wyjątkowym na tle średniowiecznej Europy uciskiem chłopów w Polsce polemizuje O. B alzer, Z zagadnień ustrojowych Polski, Warszawa 1985 (wydanie oryginału: 1915), s. $85 \mathrm{i} \mathrm{n}$.

${ }^{42}$ Ibidem, s. 134 i dokument $\mathrm{nr}$ 204. Być może ten właśnie zwrot ma glównie na myśli G. Sch e u e rmann, kiedy w biogramie Stenzla (Das Breslau-Lexicon, t. II, Dülmen 1994, s. 1664) pisze, że to ein glänzendes Werk, das heute geflissentlich als inopportun verscheigen wird, keinsefalls nur polnischerseits.

${ }^{43}$ Zwięźle o stereotypach na temat Polaków krążących wśród Niemców w XVIII-XIX w. zob. D. Łuka si ew icz, ,Niemieckie psy" $i$,polskie świnie" oraz inne eseje z historii kultury, Gdynia 1997, s. 102-112.

${ }^{44}$ Stenzel, Tzschoppe, s. 140. Wątek ten ciągnie się w niemieckim dziejopisarstwie do dziś. Despotyzm Piastów ustąpił poszanowaniu praw jednostki dopiero wraz z niemieckim prawem, głosi W. K u h n, Neue Beiträge zur schlesischen Siedlungsgeschichte, Sigmaringen 1984, s. 2-3. To Niemcy dokonali europeizacji leżącego na peryferiach cywilizacji Sląska utrzymuje 
Nie ulega zatem wątpliwości, że dzieje upowszechnienia prawa niemieckiego to - zdaniem Stenzla - realizacja idei wolności. Prawo niemieckie to uwolnienie od ciężarów prawa polskiego, zniesienie poddaństwa, zwolnienie od sądownictwa kasztelańskiego ${ }^{45}$. Ponieważ książę rządzil za pośrednictwem szlachty, która miała monopol w sprawowaniu urzędów ${ }^{46}$, to wyjęcie poddanych spod władzy prawa polskiego osłabiało pozycję wszechwładnych urzędników. Zastąpienie rozlicznych ciężarów i powinności ściśle określonym „podatkiem gruntowym" uderzało także we wszechwładną kastę urzędników i ogół szlachty mającej dotąd prawo zatwierdzania podatków ${ }^{47}$.

\section{4}

Zasadniczy jednak przełom w dotychczasowych stosunkach społecznych wywołany wprowadzeniem na Śląsk prawa niemieckiego to pojawienie się miast i mieszczaństwa. Pierwotnie - według prawa polskiego - nie było różnic między mieszkańcami wsi i miast. Te ostatnie były zresztą $w$ istocie również większymi wsiami, a ich mieszkańcy zmuszani do odrabiania pańszczyzny ${ }^{48}$. Miasta śląskie nie powstały w wyniku rozwoju wewnętrznego społeczeństwa tubylców $w^{49}$. Powstały na rozkaz, z reguły książąt ${ }^{50}$. Wprowadzenie prawa niemieckiego zaś było koniecznością, gdyż mieszczanami byli przybysze z Niemiec osiedlający się w słabo zaludnionej Polsce ${ }^{51}$. Powstanie samorządnych, bogatych i obwarowanych miast całkowicie zmieniło stosunek sił społecznych.

P. Moraw, Deutsche Geschichte im Osten Europas. Schlesien, hrgb N. Conrads, Berlin 1994, s. 47 i n. Odbywa się to z korzyścią dla zamieszkującej tu polskiej ludności - zaznacza U. Schmilewski, Ein opulentes Werk, N. C. Schlesien-Band, Schlesischer Kulturspiegel, 1994, nr 4, s. 56-57. Szerzej zob. M. Cetwiński, Ideologia i poznanie. Spoleczne funkcje mediewistyki ślqskiej po 1945 roku, Częstochowa 1993, s. 24 i n.; te nż e, Metamorfozy ślaskie. Studia źódloznawcze $i$ historiograficzne, Częstochowa 2002, s. 447 i n.

${ }^{45}$ Stenzel, Tzschoppe, s. 147.

${ }^{46}$ Ibidem, s. 54. Autor podkreśla, iż polska szlachta nie dzieliła się na wyższą i niższą, a tytuły komesa $\mathrm{i}$ barona to tylko znak przynależności do grona urzędników. I w tym widać wpływ na interpretację źródeł średniowiecznych znajomości zasady równości szlacheckiej obowiązującej w późniejszej Rzeczpospolitej. Zgodnie z praktyką szlacheckiej Rzeczpospolitej przypisuje Stenzel także polskiemu średniowieczu zasadẹ dożywotniego sprawowania urzęów (s. 71). Zaznacza, że inaczej niż w Niemczech urzędy polskie nie są dziedziczone (s. 70). Omawia szczególowo rodzaje i kompetencje polskich urzędów (s. 71-78).

${ }^{47}$ Ibidem, s. 147. Prawo szlachty do zatwierdzania podatków, poświadczone rzekomo dokumentem Boleslawa Rogatki z 1249 r., również wydaje się przeniesieniem praw szlacheckiej Rzeczpospolitej na stosunki średniowiecznego Śląska (s. 55).

48 Ibidem, s. 93, 100.

49 Ibidem, s. 129.

${ }^{50}$ Ibidem, s. $128-129$.

sl Ibidem, s. 93. 
W miastach liczyły się tylko trzy czynniki władzy: książę, wójt i rada miejska ${ }^{52}$. Z czasem eliminowano wpływy księcia i wójta, a miasta stawały się w pełni samorządnymi gminami.

„Książkę w książce” kończy hymn na cześć lokalnej samorządności jako gwarancji wszelkiego oświecenia. Samorząd lokalny to - zdaniem Stenzla - szkoła ucząca, jak odróżniać anarchię od rozumnej wolności. Ta ostatnia to zrozumienie, że tak długo, jak istnieć będzie państwo, tak długo istnieć muszą obowiązki obywateli. Państwo - sądzi wroclawski historyk - to subtelna równowaga swobód i obowiązków. Dla zachowania tej równowagi niezbędne są właśnie samorządne gminy ${ }^{53}$.

Stenzel nie ukrywa, iż jego praca historyczna ma, oprócz naukowych, także polityczne cele. Rozumna polityka miala wszak wyrastać ze znajomości tradycji, odpowiadać historycznie ukształtowanemu charakterowi narodowemu. A niemiecki charakter narodowy - sądził ten deputowany do frankfurckiego i erfurckiego parlamentu - wyrażał się najlepiej właśnie w formie wolnej samorządnej gminy.

\section{5}

Michał Bobrzyński uderza niekiedy $w$ ton, zdawałoby się podobny wywodom Stenzla. Inaczej jednak rozkłada akcenty i w konsekwencji snuje zupełnie inną opowieść. I tak przyszly namiestnik Galicji sądzi, że książęta piastowscy cieszyli się władzą absolutną.

Znieśli oni wszelki ślad samoistnego bytu szczepów i ludów, mianowicie zgromadzenia wiecowe, zacierali nawet ich terytorialne granice, przerzucali ludność $\mathrm{z}$ jednych okolic $\mathrm{w}$ drugie, mieszali je ze sobą nawzajem, a całe państwo celem lepszego zarządu podzielili na drobne powiaty, na których czele postawili urzędników, przez siebie mianowanych i ślepo od siebie zależnych ${ }^{54}$.

Urzędników tych istniało, podobno, dwa odrębne rodzaje $e^{55}$. Pierwszy to kasztelanowie $\mathrm{z}$ władzą wojskową $\mathrm{i}$ sądową, drugi to urzędnicy skarbowi. Władca był wlaścicielem calej swej ziemi $w$ swym państwie - stwierdza Bobrzyński i dodaje:

$\mathrm{Na}$ ziemi książęcej siedziała więc cała ludność, a książę sam przez urzędników swoich nadzorował i kierował jej pracą. Jedni musieli się oddawać myślistwu, drudzy chowowi bydła i rolnictwu, inni rzemiosłom, w miarę zdolności, potrzeby i rozkazu. Osady rzemieślnicze mieściły się zwykle w pobliżu grodów królewskich lub u ich stóp, tworząc tak zwane „podgrodzie” lub „,podzamcze”

s2 Ibidem, s. 204 i n.

${ }^{53}$ Ibidem, s. 263-265.

${ }^{54}$ M. Bobrzyński, Dzieje Polskie..., s. 114.

${ }^{55}$ Loc. cit. 
i nadając grodowi pozór zewnętrzny miasta ${ }^{56}$. Całe państwo - pisze dalej Bobrzyński - było więc niejako jedną wielką wsią, a cała ludność była ludnością wieśniaczą. Los tej ludności był ciężki. Przeciążona służbą wojskową i rozlicznymi daninami i powinnościami, nie miała żadnej własności gruntowej, niepewna jutra czekała, gdzie ją każdej chwili rozkaz książęcy przerzucis?

Czerpie Bobrzyński z pracy Stenzla fakty czy to, co za fakty uważa. Podobnie określa kompetencje urzędników i obowiązki poddanych. Identyczne dla obu historyków jest tło, na jakim kreślą obraz najdawniejszej historii piastowskiej Polski. Prymitywnego rolniczego kraju zamieszkałego przez zniewolonych wieśniaków. O ile jednak Stenzel potępia wszelki despotyzm, raczej szlachty niż księcia, to Bobrzyński widzi w panującym ojca ludów, zlaczonych węłami pokrewieństwa, który rozkazujqc i rzqdzq̨ nieograniczenie, wychowuje spoleczeństwo maloletnie ${ }^{58}$. Te monarchiczne tęsknoty za silną władzą wynikają z faktu, iż przyszły namiestnik Galicji spogląda na przeszłość Polski przez pryzmat jej upadku spowodowanego - jak sądzi - nadmiarem wolności, a nie jej niedostatkiem. Branie katastrofy upadku za punkt wyjścia w pogladzie na przeszlość - pisze Smoleński - jest z gruntu rzecza falszywq, dla nauki historycznej szkodliwa. Fakt upadku państwa, ważny dla historii czasów następnych, bezzasadnie zostal wzięty za motyw zasadniczy przy badaniu dziejów przedrozbiorowych ${ }^{59}$. Mit piastowskiego absolutyzmu, źródłowo nieuzasadniony, bierze zatem początek z porozbiorowego wstrząsu. Historyczna rzeczywistość Polski porozbiorowej uczyniła ten mit niezwykle żywotnym ${ }^{60}$.

\section{6}

Tęsknota za silną władzą centralną powodowała, iż Stenzla apologia samorządności gmin ${ }^{61}$ nie znajdowała zrozumienia wśród polskich historyków. W konsekwencji widziano w nim niemal wyłącznie cudzoziemca, który przysporzyl materialu źródłowego do dziejów Polski ${ }^{62}$. Chętnie cytuje sį̨ zebrane przez niego dokumenty. Rzadko natomiast przyznaje się, że on też pierwszy zająl sie procesami wewnetrznymi na Ślasku w XIII wieku: interesowaly go zagadnienia gospodarcze $i$ ustrojowe ${ }^{63}$. Mimo tego pionierstwa i niewątpliwej

${ }^{56}$ Loc. cit.

57 Ibidem, s. 115.

${ }^{58} \mathrm{~W} . \mathrm{Smoleński,} \mathrm{Szkoly} \mathrm{historyczne} \mathrm{w} \mathrm{Polsce} \mathrm{(glówne} \mathrm{kierunki} \mathrm{poglqdów} \mathrm{na} \mathrm{przeszlość),}$ Warszawa 1986 , s. 117.

59 Ibidem, s. 136.

${ }^{60}$ Por. szeroko: J. A d a m u s, Monarchizm i republikanizm w syntezie dziejów Polski, Lódź 1961.

${ }^{61}$ Stenzel, Tzschoppe, s. 177, gdzie kąśliwa uwaga, iż uniformizacja to cel dopiero współczesnej mu administracji.

${ }^{62}$ W. Smoleński, Szkoly..., s. 78.

${ }^{63}$ B. Zi e n tara, Henryk Brodaty $i$ jego czasy, Warszawa 1975, s. 324. 
inspiracji, jaką stanowiła „książka w książce” dla historyków polskich zajmujących się stosunkami gospodarczymi i społecznymi za pierwszych Piastów, cytowana jest wyłącznie incydentalnie jako źródło informacji o zaginionym rękopisie żagańskim ${ }^{64}$. Nie pojawia się natomiast - choć powinno

- dzieło Stenzla jako prekursor wspólczesnych polskich koncepcji historiograficznych.

Prawda, że wrocławski historyk należal do pierwszych piewców kolonizacji niemieckiej w Europie środkowej, niosqcej, jego zdaniem, wolność i cywilizacje do krajów, gdzie ludność tkwila $w$ zacofaniu $i$ niewoli ${ }^{65}$. Ma rację Benedykt Zientara, kiedy dalej tak pisze:

Między wydaną w 1830 roku „Historią państwa pruskiego” a ogłoszonym w 1853 roku pierwszym tomem „Historii Sląska” wyraźnie widać rosnącą niechẹć autora do Polaków i Słowian w ogóle, odpowiadającą ówczesnym zmianom $w$ obliczu niemieckiego liberalizmu, przechodzącego od tendencji demokratycznej do konserwatywnego nacjonalizmu" "s6.

Nie jest to jednak powód, aby zapominać, iż to on wskazał historykom polskim źródła i metody umożliwiające tworzenie modelu organizacji gospodarczej państwa piastowskiego w X-XIII w. I sam pierwszy taki model stworzył. Dzieło Stenzla niewątpliwie stoi u początku badań gospodarczej, społecznej oraz prawnej problematyki najdawniejszej historii Polski. Szkoda, że nie pamiętają o tym współcześni nam historycy, bo historia problemu zawsze stanowi część rozwiązania samego problemu. Zwłaszcza w przypadku wiedzy tak uwikłanej w sprawy epoki współczesnej jak historia. Choćby to była historia odległych nawet czasów. Warto więc przypomnieć tezy dzieła opublikowanego jeszcze w 1832 roku.

${ }^{64}$ K. M odze lewski, Chlopi w monarchii wczesnopiastowskiej, Wrockaw 1987, s. 85, przyp. 47. Chodzi o wzmiankę o naturze narzazu. Ustalenie przedmiotu tej daniny przypisuje autor K. Buczkowi, choć tak samo wcześniej charakteryzuje ją Stenzel (s.13).

${ }^{65}$ B. Zientara, Henryk Brodaty..., s. 324.

${ }^{66}$ Loc. cit. 